\title{
Endocrine control of energy metabolism in the cow: the effect on milk yield and levels of some blood constituents of injecting growth hormone and growth hormone fragments
}

\author{
BY J. A. BINES, I. C. HART AND S. V. MORANT \\ National Institute for Research in Dairying, Shinfield, Reading RG2 9AT, Berkshire
}

(Received I9 February 1979 - Accepted 14 August 1979)

\begin{abstract}
1. Circulating concentrations of some hormones and metabolites and nitrogen balance were measured in lactating beef and dairy cows given daily injections of growth hormone (GH) and were compared to values before injection. Changes in milk yield and composition were recorded in these cows and in additional cows injected with GH fragments.

2. GH, but not GH fragments, raised milk yield while milk composition did not change. GH injection caused a large, rapid increase in the level of the hormone in blood and slower, smaller increases in the concentrations of insulin, prolactin and thyroxine. Blood metabolite levels were unaltered except for a rise in glucose concentration in beef cows during GH injection and a fall in 3-hydroxybutyrate concentration in the same cows after the injections ceased. An increase in $\mathbf{N}$ output in milk was partly balanced by a reduction in urinary $\mathbf{N}$ so that $\mathbf{N}$ retention did not change significantly.

3. GH caused a reduction in food intake in the beef cows.

4. The results are discussed in relation to control of partition of nutrients in the lactating cow, where $\mathrm{GH}$ is considered to play an important role. It was concluded that this role may be in increasing the supply of energy metabolites for milk synthesis, rather than a direct effect on the activity of the mammary gland.
\end{abstract}

It is well known that there are differences, both between and within breeds of cattle, in the partitioning of energy between milk synthesis and body tissues (Bines \& Hart, 1978). At the peak of lactation, cows of modern dairy breeds often produce more than $30 \mathrm{~kg} \mathrm{milk} / \mathrm{d}$. This fact, in conjunction with an appetite which is generally low in early lactation (Bines, 1979), results in a requirement of energy for milk synthesis which is often greater than the amount of energy available from the diet, and the resultant deficit is made good by the mobilization of body tissue. The chemical composition of the body tissue thus lost is not known but is thought to consist largely of fat. Associated with loss of live weight during early lactation in dairy cows, are high plasma levels of growth hormone (GH) and low levels of insulin compared to levels in the same cows later in lactation, or to levels in low-yielding cows in early lactation (Hart et al. 1978). Also, changes in milk yield are directly correlated with changes in plasma GH concentration; whilst changes in plasma insulin are positively correlated with live weight change (Hart et al. 1979). These and numerous other observations have led to the hypothesis that, in the present context, GH plays a catabolic role, whilst insulin is anabolic (see Bines \& Hart, 1978; Hart et al. 1978).

It has been shown that injections of $\mathrm{GH}$ into lactating cows will increase milk production in both short-term (Hutton, 1957; Bullis et al. I965; Machlin, 1973) and long-term experiments (Brumby \& Hancock, I955; Machlin, 1973). The increased milk yields were often accompanied by an increase in the efficiency of food utilization for milk production, but it was not clear how these changes had come about. Accordingly, in order to assess the effects on yield and composition of milk, an experiment was carried out in which GH was injected daily into cows in mid-lactation, when there is normally a steady decline in milk yield from week to week. Extensive measurements of hormones and metabolites in blood plasma, together with determinations of nitrogen balance, were made to obtain more 
information on the mechanism by which GH stimulates milk production in cattle. Because of known differences between high- and low-yielding cows (Hart et al. 1978) in GH levels during lactation, it was decided to conduct the experiment on animals of each type (beef and dairy breeds) to see if there was any difference in response.

In view of the high cost of isolating and purifying pituitary $\mathrm{GH}$, it would be of considerable interest if a fragment of the hormone could be identified which has the same effect on milk yield as the native hormone, yet which could be easily and cheaply synthesized in the laboratory. Accordingly, three fragments of GH of known amino-acid sequences were tested in a second experiment for their effects on the yield and composition of milk.

\section{EXPERIMENTAL}

\section{Expt I}

Two Friesian and two Hereford-cross cows, each in the seventh month of the second lactation were available for the experiment and were examined over a period of $25 \mathrm{~d}$. The cows were given a restricted ration ( $\mathrm{I} \mathrm{kg} / \mathrm{d}$ ) of a diet containing $(\mathrm{g} / \mathrm{kg}) 100$ hay and 900 cubed dairy concentrate, in two equal portions immediately before the cows were milked at 06.00 and $\mathrm{I} 6.00$ hours. The cows were housed in individual standings in a cowshed. Milk yield was recorded and the composition was determined on bulked daily samples from days 5-2I. The cows were injected subcutaneously with $30 \mathrm{mg} \mathrm{GH}$ (NIH-GH-B9; 0.98 $\mathrm{U} / \mathrm{mg}$ dissolved in sterile saline $(9 \mathrm{~g}$ sodium chloride/l)) once daily, for $7 \mathrm{~d}$ (days 9- 5 inclusive; see Fig. I). $\mathrm{N}$ balances for a $6 \mathrm{~d}$ period (Bines \& Balch, 1973) were conducted on days I-6 and IO-I5 inclusive and blood samples were taken at hourly intervals from cannulas previously inserted into a jugular vein, for $24 \mathrm{~h}$ before and $24 \mathrm{~h}$ after the first $\mathrm{GH}$ injection on days 8 and 9 and for $48 \mathrm{~h}$ after the last injection on days 15 and 16 . Plasma was separated by centrifugation at $4^{\circ}$ and stored at $-20^{\circ}$ until analysed for $\mathrm{GH}$, insulin, prolactin, thyroxine, glucose, non-esterified fatty acids (NEFA), urea, I-lactate and 3-hydroxybutyrate (BHB) by methods used previously (Hart et al. 1978). Because of the short duration of the injection period, no attempt was made to monitor possible changes in the live weight of the cows.

\section{Expt 2}

Six Friesian cows in the fifth and sixth months of lactation received a diet containing $860 \mathrm{~g}$ concentrate $/ \mathrm{kg}$; the daily allowance of $14.6 \mathrm{~kg}$ was given in two equal portions at milking times. Weeks I, 3 and 5 of the 5-week experiment acted as control periods, with no injections being given. In weeks 2 and 4 , the cows were injected subcutaneously with $5 \mathrm{ml} / \mathrm{d}$ of a solution in saline containing $\mathrm{I} .4 \mathrm{mg}$ fragment $(a)$ or $3.0 \mathrm{mg}$ fragment $(b)$ or $(c)$, according to the following plan:

$\begin{array}{rrrrrrr}\text { Cow no. } & 71 & 72 & 73 & 74 & 75 & 76 \\ \text { Week 2 } & a & b & b & c & a & c \\ \text { Week 4 } & b & a & c & a & c & b\end{array}$

The fragments of bovine GH (structure of GH given by Wallis (1975)) were (a) amino acid residues $95-104,(b)$ 109-I I $4,(c)$ I I 6-I 24 . Milk yields were recorded daily and bulked samples analysed for fat, lactose and protein. Values for each cow during each injection period were compared with mean values for the same cow in the week before and the week after each week of injection. 
Table I. Expt. 1. Changes in yields (percent of value before injection) of milk and milk constituents and in milk composition resulting from the injection of growth hormone in Friesian and Hereford cows

\begin{tabular}{|c|c|c|c|c|}
\hline & Friesian & Hereford & Mean & SE of mean ( $2 \mathrm{df})$ \\
\hline \multicolumn{5}{|l|}{ Yield } \\
\hline Milk & 12.5 & $17 \cdot \mathrm{I}$ & $14^{-8 *}$ & 2.84 \\
\hline Fat & $8 \cdot I$ & 50.6 & $29-3$ & 13.00 \\
\hline Lactose & 12.8 & 18.5 & $15 \cdot 7^{*}$ & $2 \cdot 56$ \\
\hline Protein & 14.5 & 12.5 & $13.5^{*}$ & $2 \cdot 4 \mathrm{I}$ \\
\hline \multicolumn{5}{|c|}{ Composition } \\
\hline Fat & $-4 \cdot 5$ & $28 \cdot 3$ & $11 \cdot 9$ & $8 \cdot 23$ \\
\hline Lactose & -0.1 & $2 \cdot 2$ & $I \cdot I$ & 0.78 \\
\hline Protein & $1 \cdot 2$ & $-3 \cdot 2$ & $-1 \cdot 0$ & 2.56 \\
\hline
\end{tabular}

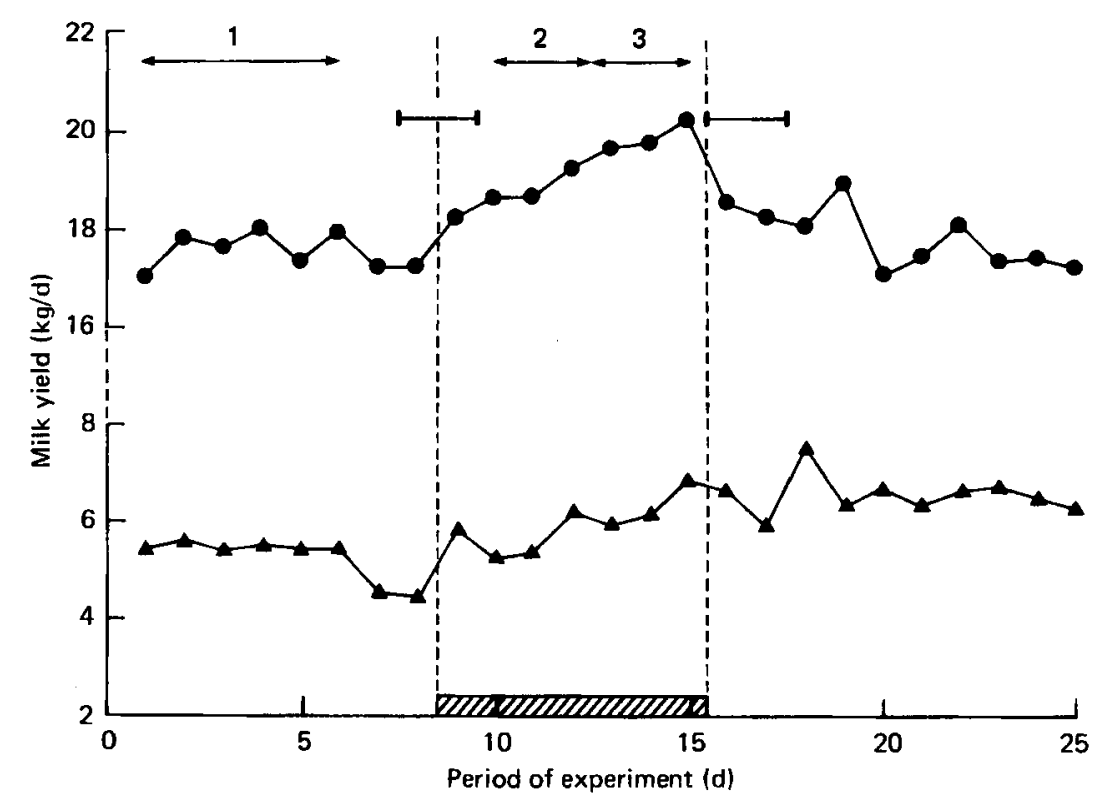

Fig. I. Expt. I. Design of experiment and mean daily milk yields $(\mathbf{k g})$ of Friesian $(--)$ and Hereford $(\Delta-\Lambda)$ cows before, during and after a period $(D)$ of growth hormone injection. , period of nitrogen balance; $\mapsto$, period of bleeding.

\section{Statistical methods}

The significance of breed effects, period effects and their interactions in Expt I were determined by split-plot analyses of variance. The hormone and metabolite concentrations were transformed to logarithmic units before analysis.

Expt 2 was a balanced incomplete block design. The analysis provides estimates of treatment effects adjusted to take account of the different animals receiving each treatment (Cochran \& Cox, 1957). 
Table 2. Expt. I. Changes in yields (percent of value before injection) of milk and milk constituents and in milk composition in a $3 d$ period after seven daily injections of growth hormone in Friesian and Hereford cows

$\begin{array}{lccr} & \text { Friesian } & \text { Hereford } & \text { SE (2 df) } \\ \text { Yield } & & & \\ \text { Milk } & 4 \cdot 4 & 21 \cdot 1^{*} & 3 \cdot 97 \\ \text { Fat } & 7 \cdot 4 & 94 \cdot 4 \dagger^{*} & 24 \cdot 40 \\ \text { Lactose } & 5 \cdot 0 & 19 \cdot 8^{*} & 2 \cdot 20 \\ \text { Protein } & 11 \cdot 7 & 28 \cdot 5^{*} & 5 \cdot 33 \\ \text { Composition } & & & \\ \text { Fat } & 2 \cdot 7 & 60 \cdot 0 \dagger & 18 \cdot 77 \\ \text { Lactose } & 0 \cdot 1 & -1 \cdot 1 & 1 \cdot 50 \\ \text { Protein } & 6 \cdot 3 & 6 \cdot 0 & 2 \cdot 79 \\ & * P<0.05,+P<0 \cdot \text { I. } & & \end{array}$

Table 3. Expt I. Changes in the fate of dietary nitrogen resulting from the injection of growth hormone into lactating Friesian and Hereford cows

\begin{tabular}{|c|c|c|c|c|c|}
\hline $\begin{array}{l}\text { Balance no. ... } \\
\text { Days of experiment ... }\end{array}$ & $\begin{array}{c}\mathrm{I} \\
(\mathrm{g} \mathrm{N} / \mathrm{d})\end{array}$ & $\begin{array}{c}2 \\
10-12 \\
(\% \text { increase })\end{array}$ & SE (2 df) & $\begin{array}{c}3 \\
13-15 \\
\text { (\% increase) }\end{array}$ & SE (2 df) \\
\hline $\begin{array}{l}\text { Milk } \\
\text { Friesian } \\
\text { Hereford }\end{array}$ & $\begin{array}{l}81 \cdot 9 \\
29 \cdot 2\end{array}$ & $\begin{array}{r}0.3 \\
-0.1\end{array}$ & 6.53 & $\begin{array}{l}14.5{ }^{\dagger} \\
12.5^{\dagger}\end{array}$ & 3.41 \\
\hline $\begin{array}{l}\text { Urine } \\
\text { Friesian } \\
\text { Hereford }\end{array}$ & $\begin{array}{l}\text { I I } 6.7 \\
\text { I } 43 \cdot 1\end{array}$ & $\begin{array}{l}-23 \cdot 6^{*} \\
-16.3\end{array}$ & 4.49 & $\begin{array}{l}-28.6 \dagger \\
-38.5^{*}\end{array}$ & $6 \cdot 83$ \\
\hline $\begin{array}{l}\text { Faeces } \\
\text { Friesian } \\
\text { Hereford }\end{array}$ & $\begin{array}{l}70 \cdot 6 \\
66 \cdot 1\end{array}$ & $\begin{array}{l}-3 \cdot 4 \\
-9.2\end{array}$ & 8.94 & $\begin{array}{l}-5.0 \\
-9.3\end{array}$ & $5 \cdot 48$ \\
\hline $\begin{array}{l}\text { Retained } \\
\text { Friesian } \\
\text { Hereford }\end{array}$ & $\begin{array}{l}39 \cdot 2 \\
68 \cdot 4\end{array}$ & $\begin{array}{c}40.7 \\
19.6 \\
* P<0.05, \dagger \\
\\
\text { RESUL } \\
\text { Expt }\end{array}$ & $\begin{aligned} & 17 \cdot 2 \\
< & 0.1\end{aligned}$ & $\begin{array}{r}29 \cdot 8 \\
-30.4\end{array}$ & $3 I \cdot I$ \\
\hline
\end{tabular}

During the $3 \mathrm{~d}$ before injections started the mean milk yields were 17.45 and $4.76 \mathrm{~kg}$ for the Friesians and the Herefords respectively and milk composition, which did not vary between the breeds, was $(\mathrm{g} / \mathrm{kg})$ I $7 \cdot 2$ fat, 32.3 protein, $46 \cdot 4$ lactose. During the injection period, milk yield gradually rose and the mean yields during the last $3 \mathrm{~d}$ in both breeds were approximately $15 \%$ higher than in the $3 \mathrm{~d}$ before the first injection $(P<0.05)$. (Table $\mathrm{I}$ and Fig. $\mathrm{I}$ ). There were similar increases in the yield of protein $(P<0.05)$ and lactose $(P<0.05)$, but the yield of fat was very variable and even an increase of approximately $50 \%$ in the Herefords failed to achieve significance. There was no evidence of a change in milk composition in either breed (Table I).

On the third to fifth days after the last GH injection, the yields of milk, fat, lactose and protein in the Friesians were only slightly higher than in the pre-injection period $(P>0 \cdot \mathrm{I})$. In the Herefords however, the yields of milk and lactose remained higher by approximately $20 \%(P<0.05)$ and the yield of protein was $28 \%$ higher than it was before injections began (Table 2). The yield of fat was increased by $94 \%(P<0.1)$, an increase of $60 \%$ in the fat content of the milk $(P<0 \cdot I)$. 
Because of the gradually-increasing response of milk yield to $\mathrm{GH}$ injection, the results of the $\mathbf{N}$ balance measurement made during the injection period were analysed as two separate $3 \mathrm{~d}$ balances (balance no. 2 (days $10-12$ ) and 3 (days 13-15); Fig. I, Table 3). Balance no. I was the $6 \mathrm{~d}$ balance conducted before injections began. Balance no. 3 covered the period (days 13-15) over which milk yields were averaged in the analysis summarized in Table I. Thus, the percentage increase in $\mathrm{N}$ in the milk in balance no. 3 relative to balance no. I was the same as the increase in the yield of protein shown in Table $\mathrm{I}$. The decrease in urinary $\mathrm{N}$ was $29 \%$ in the Friesians $(P<0.1)$ and $39 \%$ in the Herefords $(P<0.05)$ and more than accounted for the extra $\mathrm{N}$ in milk. Small reductions in the amount of faecal $\mathbf{N}$ were not significant.

There was a decrease in urinary $\mathrm{N}$ in balance no. 2 relative to balance no. I (Friesians $P<0.05$, Herefords $P<0.1$ ). This reduction occurred before any increase in the amount of $\mathrm{N}$ in the milk and most of it appeared to have been retained, although the increase in $\mathrm{N}$ balance was not significant in either group. In one Hereford, an exceptionally-low value for $\mathrm{N}$ retained in balance no. 3 was due to a depressed food intake during the balance (see $\mathrm{p}$. 183 ); in the other Hereford, $\mathrm{N}$ retained in balance no. 3 was only $4.5 \%$ lower than in balance no. I.

During the $7 \mathrm{~d}$ period of the $\mathrm{GH}$ injection, intake of the concentrate portion of the ration was depressed $(P<0.05)$ to $7.75 \mathrm{~kg} / \mathrm{d}$ in the Herefords. Occasional small refusals resulted in a mean intake of $9.68 \mathrm{~kg}$ concentrate/d in these cows in the $7 \mathrm{~d}$ periods before and after injection. GH had no effect on intake of concentrates by the Friesians which ate their food quickly buth before and during the injection period. GH did not affect hay intake in cows of either breed.

The geometric mean concentrations of the hormones and metabolites in the two breeds for each day of sampling are shown in Table 4. Differences between breeds in the over-all plasma concentrations of some hormones and metabolites have been found in a previous study (Hart et al. 1978). Although no breed differences attained significance in this experiment, because of the small number of animals involved, the over-all values were broadly similar to those observed previously. The one exception is BHB which in this experiment was slightly higher in the Herefords than in the Friesians; previous work had suggested that BHB was higher in Friesians than in Herefords during lactation. Plasma BHB is also one of the metabolites measured which appeared to have been affected by the GH injections. In the two Hereford cows, the BHB concentrations in period 4 were lower than in any other period $(P<0.05)$, but there was no such effect in the Friesians. Similarly, plasma glucose was significantly higher $(P<0.05)$ in period 3 in the Herefords, but was unchanged in the Friesians.

There were no increases in prolactin levels in the $24 \mathrm{~h}$ period after the first injection, but after the final injection the mean concentrations in both breeds had risen to approximately twice those in the period before injections began $(P<0.01)$. In the second $24 \mathrm{~h}$ period after the last injection the levels were still approximately $40 \%$ higher than in the pre-injection period $(P<0.05)$.

Thyroxine concentrations also failed to show any change after the first injection of $\mathbf{G H}$. But in the first $24 \mathrm{~h}$ after the last injection, the concentrations were approximately $35 \%$ higher and remained at that level during the next $24 \mathrm{~h}$.

The increase in plasma insulin throughout the $24 \mathrm{~h}$ after the first $\mathrm{GH}$ injection was $26 \%$ in the Friesians $(P>0.1)$ and $51 \%$ in the Herefords $(P<0.1)$. After the final injection, the levels were increased relative to the pre-injection concentrations by $68 \%$ in the Friesians $(P<0.05)$ and by $161 \%$ in the Herefords $(P<0.01)$. In the following $24 \mathrm{~h}$, the levels fell considerably but were still significantly higher $(P<0.05)$ than before the injections began, being similar to those found immediately after the first injection. 
Table 4. Expt I. Geometric mean plasma concentrations of hormones and metabolites in Friesian and Hereford cows over $24 \mathrm{~h}$ periods before and after the first injection of growth hormone (periods I and 2) and over two $24 h$ periods following the final injection (periods 3 and 4)

$\overbrace{1}^{\text {Period }} \overbrace{3}^{3} \quad 4_{4}$
$5 \%$ least significant n-fold difference $(6 \mathrm{df})$ between periods

Growth hormone (ng/ml)

Friesian

Hereford

3

$3 \cdot 7$
$1 \cdot 9$

$17 \cdot 8$

$13 \cdot 1$

$17 \cdot 3$

$12 \cdot 3$

$4 \cdot 6$

Insulin $(\mu \mathrm{U} / \mathrm{ml})$

Friesian

Hereford

$12 \cdot$

$33 \cdot 8$

$15 \cdot 5$

$50 \cdot 9$

$20 \cdot 7$

88.2

$18 \cdot 2$

$48 \cdot 4$

Prolactin (ng/ml)

Friesian

Hereford

10.6

$12 \cdot 3$

$8+7$

20.4

$20 \cdot 4$
$17 \cdot 5$

$15 \cdot 8$

12.5

Thyroxine (ng/ml)

Friesian

Hereford

$16.3 \quad 15.8$

$22 \cdot 3$

$15 \cdot 8$
$23 \cdot 6$

$23 \cdot 8$

$23 \cdot 9$

$29 \cdot 3$

Glucose (mmol/l)

Friesian

Hereford

3.57

$3 \cdot 68$

\section{$3 \cdot 56$}

3.97

\section{$3 \cdot 29$}

$4 \cdot 82$

3.62

3.99

NEFA $(\mu \mathrm{mol} / \mathrm{l})$

Friesian

Hereford

$239 \cdot 0$

256.0

$292 \cdot 0$

$261 \cdot 0$

$255^{\circ} 0$

$238 \cdot 0$

BHB (mmol/l)

Friesian

Hereford

Urea (mmol/1)

Friesian

Hereford

L-lactic acid (mmol/l)

Friesian

Hereford

210

$242 \cdot 0$

$\begin{array}{ll}0.64 & 0.75 \\ I .08 & 0.83\end{array}$

I I 7

0.75
$I \cdot 15$

0.85
1.09

0.83

I.32

$1 \cdot 52$

$-40$

I·2 I

I. 29

$I \cdot 47$

6.68

$7 \cdot 97$

$1 \cdot 38$

$7 \cdot 38$
$7 \cdot 83$

6.90

$6 \cdot 77$

$7 \cdot 05$

0.43

0.56
0.69

0.63

0.54

0.60

0.52

$\mathbf{I} \cdot 53$

NEFA, non-esterified fatty acids; BHB, 3-hydroxybutyrate.

Concentrations of $\mathrm{GH}$ in plasma during the injection period were four to five times greater than when the cows were not injected. In general, circulating GH rose to a peak approximately $2-6 \mathrm{~h}$ after subcutaneous injection and was maintained higher than basal concentrations throughout the $24 \mathrm{~h}$ period. The response in the first $24 \mathrm{~h}$ period was as great as that in subsequent days.

Expt 2

The effects, on milk yield and composition, of the daily subcutaneous injection of the specified fragments of GH into Friesian cows are shown in Table 5. The fragments examined had no effect whatever on either milk yield or the content of fat, protein or lactose. An exceptionally small standard error for the fat content on the control period has produced an apparent difference between treatment means. However, neither the fat content in the treatment period nor the difference in content between the treatment and control periods gave any indication of a treatment effect. 
Table 5. Expt 2. The effects on milk yield $(\mathrm{kg} / \mathrm{d})$ and composition $(\mathrm{g} / \mathrm{kg})$ of daily injections of specified fragments of growth hormone $(G H)$ into six lactating Friesian cows

\begin{tabular}{|c|c|c|c|c|c|c|c|c|}
\hline $\begin{array}{l}\text { Period of expe } \\
\text { GH fragment }\end{array}$ & riment $\ldots$ & reatmen & eriod & & Control (n & $\begin{array}{l}\text { in of } \\
\text { treat }\end{array}$ & $\begin{array}{l}\text { ss before } \\
\text { at) }\end{array}$ & ad after \\
\hline residues & Milk yield & Fat & Protein & Lactose & Milk yield & Fat & Protein & Lactose \\
\hline $\begin{array}{r}95-104 \\
109-114 \\
116-124\end{array}$ & $\begin{array}{l}2 I \cdot 0 \\
2 I \cdot I \\
2 I \cdot 5\end{array}$ & $\begin{array}{l}15.2 \\
14.3 \\
13.8\end{array}$ & $\begin{array}{l}32 \cdot 3 \\
32 \cdot 9 \\
32 \cdot 4\end{array}$ & $\begin{array}{l}47 \cdot 8 \\
48 \cdot 0 \\
47 \cdot 3\end{array}$ & $\begin{array}{l}21 \cdot 4 \\
20 \cdot 5 \\
21 \cdot 4\end{array}$ & $\begin{array}{l}13 \cdot 4 \\
14.6 * \\
13 \cdot 6\end{array}$ & $\begin{array}{l}32 \cdot 2 \\
32 \cdot 8 \\
32 \cdot 4\end{array}$ & $\begin{array}{l}47 \cdot 9 \\
47 \cdot 7 \\
47 \cdot 6\end{array}$ \\
\hline (4 df) & 0.68 & 3.08 & 0.50 & 0.43 & 0.40 & 0.32 & 0.30 & 0.58 \\
\hline
\end{tabular}

\section{DISCUSSION}

The mean GH levels in blood achieved by daily injection of the hormone were approximately twice as great as the mean values previously found throughout a $24 \mathrm{~h}$ period in dairy cows at peak lactation (Hart et al. I978). However, they did not exceed the highest individual values encountered at peak lactation so that the levels resulting from injection were considered to have remained within the physiologically normal range. Although the levels of thyroxine, insulin and prolactin in both groups rose significantly in response to GH injection, the increases in their concentrations in comparison to pre-injection levels were always much less than the relative increase in $\mathrm{GH}$ concentration, and the maximum response occurred much later than that of GH. It seems likely therefore, that any changes in the cows' metabolism resulting from raised levels of $\mathrm{GH}$ would outweigh changes due to raised levels of the other hormones.

The insulin response to GH treatment was not unexpected as there is evidence that GH stimulates insulin secretion in vivo (Åkerblom et al. 1973; Sönksen, 1975). Unlike humans however, where prolonged treatment leads to a progressive diabetes, possibly as a result of pancreatic $\beta$-cell exhaustion (see Raben, 1973; Sönksen, 1975), the cows showed no reduction in plasma insulin after $7 \mathrm{~d}$ of injection. In fact there was an indication in both groups, of an accumulative effect of GH on insulin secretion. It is not yet clear whether the effect of GH on insulin is mediated via enhanced circulating glucose (see Sönksen, 1975); the fact that the insulin increment was higher at period 3 in the Herefords than the Friesians, together with a significant increase in glucose in this group, indicates that the two may be related.

The means by which GH stimulated prolactin and possibly thyroxine secretion are less clear. Prolactin increases after feeding in cattle (McAtee \& Trenkle, I97I) but the results demonstrating a prolactin response to glucose in ruminants are less conclusive (Bryant et al. 1970; McAtee \& Trenkle, I971). Circulating thyroxine may have been stimulated by the increased levels of insulin (Kumaresan \& Turner, I966).

The increases in the yields of milk, milk protein and lactose were proportionately similar for both high- and low-yielding cows, but in terms of absolute amounts, the increase for the Friesians was obviously much greater than that for the Herefords. Since the cows were not allowed to eat additional food during the injection period, indeed the Herefords consumed less, there must have been a change in the partition of nutrients towards increased milk synthesis. An increase in the apparent efficiency of milk synthesis was also a feature of other work reported on the effect of GH on milk production (Brumby \& Hancock, I955; Hutton, 1957; Machlin, 1973). In the New Zealand work (Brumby \& Hancock, 1955), GH injections over several weeks improved milk production by at least $50 \%$ at peak lactation and in late 
lactation; measurement of efficiency was complicated by the difficulty of measuring intake in grazing animals, but the authors calculated that a marked improvement had occurred. The increased milk yield reported by Machlin (1973) using highly-purified GH, was much lower and was comparable to that in the present work. The much higher response found by Brumby \& Hancock (1955) may have been due to the fact that their GH preparation contained trace quantities of other pituitary hormones.

The change in partition of dietary energy could have resulted from either a direct action of GH on the mammary gland, increasing the capability of the gland to synthesize milk, or by the hormone causing a reduction in the rate of synthesis of body tissue or even catabolism of body tissue, thus making additional nutrients available for milk production. Reduced synthesis or catabolism of body tissue are not usually associated with GH. On the contrary, in the growing animal at least, the hormone is generally associated with the laying down of newly synthesized tissue. In the present instance, we may be seeing a more specific role of the hormone in the mature animal subjected to a brief period of energy deficit. The extra $\mathrm{N}$ in milk protein was more than accounted for by a reduction in urinary $\mathrm{N}$ excretion. This suggests that the synthesis of milk protein before the injection period was not limited by the availability of $\mathrm{N}$, but by either the synthetic ability of the gland or the supply of energy to the gland. The absence of a significant decrease in $\mathbf{N}$ retention during the injection period indicates that there was no net mobilization of body protein, indeed the opposite may have been the situation, although the increase in $\mathrm{N}$ retention was not significant. It has been known for many years that $\mathrm{GH}$ stimulates $\mathrm{N}$ retention and favours the deposition of carcass $\mathbf{N}$ by stimulating the transport of certain amino acids into body tissues (Kostyo, 1973). Insulin also promotes $\mathrm{N}$ retention and exerts a profound anabolic effect on protein metabolism in skeletal muscle (Nakano et al. 1977). Rabinowitz et al. (1966) have in fact postulated that GH will oply exert its effect on protein metabolism in the presence of 'adequate' amounts of insulin. It is not surprising therefore to note the increased $\mathrm{N}$ retention, albeit not significant, between days $10-12$ and $13-15$ (Friesians only) of hormone treatment. The non-significant decrease in plasma urea during the injection period was probably a reflection of increased mammary protein synthesis and the resultant decrease in urinary $\mathbf{N}$ excretion.

The increased synthesis of milk during the period of GH injection must have increased the demand of the mammary gland for energy-yielding metabolites both as precursors of the additional lactose and protein and as a source of energy for the synthetic processes. That there were no significant decreases in the concentrations of energy-yielding metabolites measured in plasma, is an indication that the body was able to increase the entry rate of those substances into the circulation to meet these requirements for increased synthetic activity. However, it is not possible to identify whether the primary site of action of the GH was the mammary gland itself, or via some other process facilitating release of additional metabolites into the bloodstream. Because of the known lipolytic role of GH (see Jagannadha \& Ramachandran, 1977; Bines \& Hart, 1978), an increase in the concentration of plasma NEFA had been anticipated, but the small increase which occurred did not approach significance. This may have been due to the lower dose of GH used in the present study compared to that previously employed in cattle where a rise in NEFA was noted (Williams et al. 1963; Kronfeld, 1965). Bassett \& Wallace (1966) calculated that a dose of $0.2 \mathrm{mg}$ $\mathrm{GH} / \mathrm{kg}(0.7 \mathrm{U} / \mathrm{mg})$ was required to elicit a maximum lipolytic response in sheep; the daily dosage of hormone in the present experiment varied between $0.05-0.07 \mathrm{mg} \mathrm{GH} / \mathrm{kg}(0.98$ $\mathrm{U} / \mathrm{mg}$ ). An alternative explanation might be that $\mathrm{GH}$ was not able to exert its maximal effect on fat mobilization in the presence of elevated levels of insulin. Since synthesis of lactose is considered to be a rate-limiting step in milk synthesis (Kronfeld, I976), it was of interest to note that the plasma concentration of glucose, the essential precursor of lactose, 
rose significantly in the Herefords by day 7 of $\mathrm{GH}$ treatment. If this raised glucose level was due to an increase in the entry rate of glucose into the blood, it could have occurred in both Herefords and Friesians, but have been masked in the latter by a greater increase in lactose synthesis necessary for the greater absolute increase in lactose output in cows of that breed, compared to the Herefords. GH is known to increase plasma glucose in non-lactating ruminants and non-ruminants (Bassett \& Wallace, 1966; Merimee \& Rabin, I973) and also in lactating cattle (Brumby \& Hancock, 1955). The increased supply of glucose is unlikely to have come from amino acids as this would have been expected to raise rather than lower blood urea and urinary $\mathrm{N}$ excretion. GH may have increased glucose supply to the mammary gland by decreasing the utilization of glucose elsewhere.

The depression of food intake in the Hereford cows during GH injection was surprising in view of a previous report that $\mathrm{GH}$ did not affect intake in sheep during spontaneous meals (Baile \& Martin, 1971). This depression is unlikely to have been attributable to changes in blood metabolite concentrations, since these were not significant, but the changes in concentrations of other hormones may have been involved. More recently, Driver \& Forbes (1978) have suggested a possible connection between $\mathrm{GH}$ release and eating.

The results of the main experiment give a few indications of possible mechanisms involved in the galactopoietic role of $\mathrm{GH}$ in cattle, but did not identify the primary site of action of the hormone. Further specific measurements of the effect of GH on entry rate of glucose and other metabolites can be expected to clarify this issue. The results of the second experiment showed that none of the fragments examined was able to duplicate the effects on milk yield and composition, of the intact hormone. The preparation of further fragments of known constant composition is highly desirable, since if one can be found which has the same effect as the hormone, it will be potentially possible to effect long-term improvements in the efficiency of milk production by the dairy cow. A synthetic peptide corresponding to amino-acid residues $3 \mathrm{I}-44$ of human $\mathrm{GH}$ has been prepared and has been shown to have lipolytic activity in rats and tissue from rabbits (Yudaev et al. 1976). If a similar fragment could be obtained from bovine $\mathrm{GH}$, it may prove to be of considerable interest in the present context.

The authors thank Mrs K. A. M. Danby and Mr D. J. Napper for skilled technical assistance, Dr N. Petter (Imperial Chemical Industries Ltd) for providing the fragments of growth hormone, National Institute of Arthritis, Metabolism \& Digestive Diseases, National Institutes of Health, Bethesda, USA, for supplies of GH and pituitary hormones used in the radioimmunoassays and Wellcome Reagents Ltd for the bovine insulin standard.

\section{REFERENCES}

Akerblom, H. K., Martin, J. M. \& Gary, G. L. (1973). Hormone Metab. Res. 5, 34.

Baile, C. A. \& Martin, F. H. (1971). J. Dairy Sci. 54, 897.

Bassett, J. M. \& Wallace, A. L. C. (1966). Metabolism 15, 933.

Bines, J. A. (1979). In Feeding Strategy for the High-Yielding Dairy Cow, p. 23 [W. H. Broster and H. Swan, editors]. London: Granada Publishing Co.

Bines, J. A. \& Balch, C. C. (1973). Br. J. Nutr. 29, 457.

Bines, J. A. \& Hart, I. C. (1978). Proc. Nutr. Soc. 37, 281.

Brumby, P. J. \& Hancock, J. (I955). N.Z. Jl. Sci. Technol. 36A, 417.

Bryant, G. D., Linzell, J. L. \& Greenwood, F. C. (1970). Hormones I, 26.

Bullis, D. D., Bush, L. J. \& Barto, P. B. (1965). J. Dairy Sci. 48, 338.

Cochran, W. G. \& Cox, G. M. (1957). In Experimental Designs, and ed. London: John Wiley.

Driver, P. M. \& Forbes, J. M. (1978). Proc. Nutr. Soc. 37, 100A.

Hart, I. C., Bines, J. A. \& Morant, S. V. (1979). J. Dairy Sci. 62, 270.

Hart, I. C., Bines, J. A., Morant, S. V. \& Ridley, J. L. (1978). J. Endocr. 77, 333.

Hutton, J. B. (1957). J. Endocr. 16, 115. 
Jagannadha, A. \& Ramachandran, J. (1977). In Hormonal Proteins and Peptides, p. 43 [C. H. Li, editor]. New York, San Francisco and London: Academic Press.

Kostyo, J. L. (1973). In Methods in Investigative and Diagnostic Endocrinology, p. 279 [S. A. Berson and R. S. Yalow, editors]. Amsterdam and London: North Holland.

Kronfeld, D. S. (1965). J. Dairy Sci. 48, 342.

Kronfeld, D. S. (1976). Adv. Anim. Physiol. Anim. Nutr. 7, 5.

Kumaresan, P. \& Turner, C. W. (I966). Proc. Soc. exp. Biol. Med. 121, 752.

McAtee, J. W. \& Trenkle, A. (1971). Endocrinology 89, 730.

Machlin, L. J. (1973). J. Dairy Sci. 56, 575.

Merimee, T. J. \& Rabin, D. (1973). Metabolism 22, 1235.

Nakano, K., Yasui, T., Sugimoto, E. \& Ashida, K. (1977). Nutr. Rep. Int. r5, 373.

Raben, M. S. (1973). In Methods in Investigative and Diagnostic Endocrinology, p. 26I [S. A. Berson and R. S. Yalow, editors]. Amsterdam and London: North Holland

Rabinowitz, D., Merimee, T. J. \& Burgess, J. A. (1966). Diabetes 15, 905.

Sönksen, P. H. (1975). Proc. R. Soc. Med. 68, 707.

Wallis, M. (1975). Biol. Rev. 50, 35.

Williams, W. F., Lee, S. D., Head, H. H. \& Lynch, J. (1963). J. Dairy Sci. 46, 1405.

Yudaev, N. A., Pankov, Yu.A., Keda, Yu.M., Schvachkin, Yu.P., Ryabtsev, M. N. \& Chukashev, S. G. (1976). Biochemistry, N.Y. 4x, 69I. 